\title{
Kendine Özgü Riskler Üzerine Bir Literatür Derlemesi $^{1}$
}

\author{
DOI: $10.26466 /$ opus.480916 \\ Barıș Kocaarslan $^{*}$
}

* Dr. Arş. Gör., Yalova Üniversitesi, İktisadi ve İdari Bilimler Fakültesi, Yalova / Türkiye

E-Posta: bariskocaarslan@gmail.com

ORCID: 0000-0003-4492-980X

\section{Öz}

Finansal varlık fiyatlama teorileri çeşitli risk faktörlerini dikkate alarak finansal varlıkların getirilerini açıklamayı amaçlar. Bu teorilerin doğası gereği bazı kısıtları ve varsayımları içermesi gerekmektedir. Bu kısıt ve varsayımlar bazen piyasa mekanizmasının işleyişi ile uyuşmayabilir. Bu nedenle, gözlemlenen piyasa fiyatları ile finansal teorilerin tahminleri arasında sıklıkla önemli miktarda sapmalar görülmektedir. Bu sapmalarm önemli bir kaynă̆ı olarak varlikların kendine özgü riski çok sıcak bir tartışma konusudur. Kendine özgü risklerin iyi çeşitlendirilmiş portföyler oluşturarak azaltılabileceği iddiası bu tartışmanın odak noktasıdır. Bu çalışmada, literatürdeki ilgili çalışmaları gözden geçirerek sistematik olmayan (kendine özgü) risklerin fiyatlanmasının arkasındaki potansiyel nedenleri ele almayı amaçladık. Bu amaçla, sistematik olmayan risklerin karakteristiklerini daha iyi anlayabilmek için çalışmamızda ilk olarak geleneksel finans teorilerinin bazı zayıfliklarından bahsettik. Bunun yanında, kendine özgü risklerin arkasinda yatan temel nedenler ve bu risklerin piyasa mekanizmasındaki değişikliklere olan duyarlılı̆̆ın seviyesi meselesi ilgili literatürdeki geçmiş bulguların ışı̆̆ında değerlendirilmiştir. Son olarak, kendine özgü risklerin nasıl ölçüleceği ile ilgili literatürdeki önerilerden bahsedilmiştir.

Anahtar Kelimeler: Kendine Özgü Risk, Varlık Fiyatlama, Finansal Varlıklar

\footnotetext{
${ }^{1}$ Bu çalışma, Barış Kocaarslan'ın Orta Doğu Teknik Üniversitesi, Sosyal Bilimler Enstitüsü, İşletme Anabilim Dalı, İsletme Doktora tezinden esinlenilerek hazırlanmıştır.
}

OPUS (c) Uluslararası Toplum Araştırmaları Dergisi-International Journal of Society Researches ISSN:2528-9527 E-ISSN : 2528-9535

http://opusjournal.net 


\title{
A Literature Review on Idiosyncratic Risks
}

\begin{abstract}
Financial asset-pricing theories aim to explain the returns of financial assets by considering various risk factors. These theories, by nature, need to include some constraints and assumptions. These constraints and assumptions may sometimes not coincide with the functioning of the market mechanism. For this reason, a significant amount of deviations are frequently seen between the observed market prices and the estimates from financial theories. The idiosyncratic risk of the assets as an important source of these deviations is a very hot discussion topic. The argument that idosyncratic risks can be reduced by forming well-diversified portfolios is the focus of this discussion. In this study, we aim to address the potential reasons behind the pricing of non-systematic (idiosyncratic) risks by reviewing the relevant studies in the literature. To that end, in order to better understand the characteristics of non-systematic risks, we first mention some weaknesses of traditional finance theories in our study. Besides, the main reasons behind the idiosyncratic risks and the level of sensitivity of these risks to changes in the market mechanism are evaluated in the light of the previous findings in the related literature. Finally, the suggestions from the literature about how to measure idiosyncratic risks are mentioned.
\end{abstract}

Keywords: Idiosycnratic Risk, Asset Pricing, Financial Assets.

OPUS @ C Uluslararası Toplum Araştırmaları Dergisi-International Journal of Society Researches ISSN:2528-9527 E-ISSN : 2528-9535

http://opusjournal.net 


\section{Giriş}

Piyasa oyuncularının şirketlerin ve portföylerin kendine özgü risklerini sahip oldukları varlıkları çeşitlendirme yolu ile azaltabilecekleri ilgili literatürde öne çıkan bir savdır (Markowitz, 1952). Fakat, bu iddia araştırmacılar arasında tartışmalı bir konu olmaya devam etmektedir. $\mathrm{Bu}$ tartışmanın temel nedeninin iyi bilinen finansal varlık fiyatlama modellerinin kısıtlarından ve varsayımlarından kaynaklandığı ileri sürülmektedir. Buradan hareketle, biz öncelikle geleneksel finans yaklaşımlarının varsayımlarını ve bakış açılarını inceledik. Daha sonra, literatürdeki ilgili çalışmaların kendine özgü risklerin nedenleri ve karakteristiği üzerine elde edilen bulgularından ve çıkarımlarından bahsettik. Son olarak, kendine özgü risklerin hangi modeller kullanılarak tespit edilebileceği ile ilgili literatürdeki bazı önerileri ele aldık.

\section{Geleneksel Finans Yaklaşımları}

İyi bilinen geleneksel finans teorileri, ortak risk faktörlerinin varlıkların temel değeri üzerindeki etkilerini araştırmışlardır. Gözlemlenen piyasa fiyatları piyasa mekanizmasinda arz-talep dengesi ile belirlenmektedir. Bir taraftan, bu fiyatlar özellikle kısa vadede temel değerden sapmalar göstermektedir. Öte yandan, gözlemlenen fiyatlar uzun vadede temel değerine yaklaşma eğilimindedir (Smith, 1776). Etkin piyasa hipotezi (Fama, 1970), gözlenen fiyatın ve temel değerin birbirine çok yakın olduğu iddiasına dayanmaktadır. Özetle, varlık fiyatlandırması ile ilgili temel tartışma, bir varlığın gözlemlenen fiyatı ile temel değeri arasındaki ilişkinin ne kadar yakın olduğu üzerinedir.

Bir varlığa sahip olmak, o varlığın bize sağlayacağı gelecekteki nakit akışlarına ilişkin hak talep etmemizi sağlar. Bu açıdan bakıldığında, bir varlığın temel değeri gelecekte beklenen nakit akışlarına bağlıdır. Şimdiki-değer modeli, beklenen nakit akışlarının (temettü ödemelerinin) şimdiki değere uygun bir iskonto oranıyla iskonto edildiği varsayımına dayanmaktadır (Campbell, Lo ve MacKinlay, 1997). Ancak, temettü getirisini tahmin etmek ve mevcut değeri elde etmek için uygun iskonto oranını belirlemek oldukça zordur. Etkin piyasa hipotezi (EMH) (Fama, 
1970), mevcut bilgilere göre, temel değeri ve nihayetinde piyasa fiyatlarını açıklayabileceğimizi savunur. EMH, piyasa katılımcıları arasında gelecekteki beklentileri şekillendiren mevcut bilgilere bağlı olarak piyasa beklentileri konusunda bir fikir birliği olduğunu varsayar. Fakat, piyasadaki mevcut bilginin bir varlığın esas değerinin fiyatlanabilmesi için yeterli olabileceği ve bir varlık ile ilgili bilgiye piyasa oyuncularının tamamının ulaşabileceği iddiaları tartışmaya açıktır. Bunun yanında, geleceğe yönelik nakit akışları üzerinde beklentilerin oluşturulmasında varlıkların kendine özgü özelliklerine dayanan yatırımcıların öznel fikirleri ve risk algıları önemli rol oynamaktadır. Ampirik literatür genel olarak şimdiki-değer modeli ve Sermaye Varlıklarını Fiyatlandırma Modeli (Sharpe, 1964; Lintner, 1965) gibi diğer statik modellerin varlıkların zamanla değişen risk derecelerini dikkate almadı̆̆ı için varlıkların fiyatlarındaki değişiklikleri açıklamakta zaman zaman yetersiz olduğuna dair çeşitli bulgular sunmuştur. $\mathrm{Bu}$, zamanla değişen risk faktörlerini hesaba katan dinamik modellerin dikkate alınması gerektiğini göstermektedir.

Özetle, çeşitli varsayımlara ve önceden belirlenen risk faktörlerine dayanan klasik teorilerin tahminleri ile piyasada gözlenen fiyatlar genellikle tam olarak örtüşmemektedir. Buda bize bu teorilerin dikkate aldığ 1 ortak risk faktörleri dışında firmaların, endüstrilerin ve benzer karakteristiklere sahip varlıklardan oluşan portföylerin kendine özgü risklerinin fiyatlanabileceği ihtimalini gösterir. Özellikle kısa dönemde hisse senedi piyasalarındaki fiyat değişimlerini açıklamakta statik modellerin daha fazla güçlük çektiği görülmektedir. Bunun başlıca nedenlerinden biri, bir varlığın volatilitesinin zaman içinde yatırımcıların piyasanın geleceği ile ilgili farklılaşan beklentilerine bağlı olarak ani ve önemli ölçüde değişmesidir (Levy, 1978).

\section{Kendine Özgü Riskin Potansiyel Nedenleri}

Mevcut literatür kendine özgü riskin beklenen getiriler üzerindeki etkilerine dair güçlü kanıtlar sunmaktadır (Levy, 1978; Barberis ve Huang, 2001; Goyal ve Santa-Clara, 2003). Etkin yatırım stratejileri kendine özgü (sistematik olmayan) risklerden korunmak için dikkatli bir risk yönetimini gerektirir. Oluşturulan portföylerin davranışları içeriğindeki 
varlıkların farklı özelliklerinden dolayı ekonomik koşullardaki dalgalanmalara bağlı olarak birbirlerinden farklılaşır. Dolayısı ile, şirket hisse senetlerinin ve portföylerin kendine özgü riskleri doğal olarak zamanla değişmektedir. Bu nedenle, etkin yatırım stratejileri geliştiren fon yöneticileri ekonomik darboğazlarda (örneğin artan volatilite periyotlarında), oluşturdukları portföylerin içeriğindeki varlıkların kendine özgü risklerinden korunabilmek için portföylerinin kompozisyonunu sürekli olarak güncellemelidir. Campbell ve diğ. (2001) çeşitlendirme stratejilerinin farklı özelliklere sahip olan portföylere çok sayıda hisse senedi dahil edilmesini gerektirdiğini göstermişlerdir.

Literatürde piyasaya yeni giren küçük şirketlerin hisse senedi getirilerinin volatilitesinin makroekonomik etkilere daha açık olduğu ve dolayısı ile daha riskli oldukları tespit edilmiştir (Campbell ve diğ., 2001; Bali ve diğ., 2005). Bu şirketler hakkında dışarıdan finansal kaynak bulmada yaşanılan zorluklardan dolayı finansal kurumlardan elde edilen krediler aracılığı ile dışarıya bilgi aktarımı sınırlıdır. Daha genç ve küçük şirketlerin temel faaliyetleri ile ilgili bilgi eksikliği onların kendine özgü risklerinde artışa neden olur. Buradan hareketle, küçük şirketlerin hisse senedi getirilerinin oynaklığının konjonktürel dalgalanmalara daha duyarlı olması beklenir. Bu duyarlılık küçük şirketlerin hisse senetleri için daha düşük miktarda işlem hacmine neden olur.

Finans literatüründe kendine özgü risklerin kaynağı ile ilgili farklı görüssler ortaya konmuştur. Bunlardan bazıları piyasada varlıklar ile ilgili bilginin mevcut olup olmadığı ile ilgilenir. Kaldıraç riski şirketlerin nakit akış riskleri hakkında piyasaya bilgi sağlayarak şirketlerin kendine özgü risklerini etkileyebilir (Black, 1976; Christie, 1982). Türev piyasalar, gelecekteki nakit akışları hakkında piyasa oyuncularına bilgi akışını hızlandırabilir ve bunun sonucu olarak varlığa özgü volatiliteyi azaltabilir (Grossman, 1988). Bununla birlikte, Stein (1987), daha fazla bilgiye sahip olan spekülatörler tarafından yapılan riskten korunma ve yatırım stratejilerindeki değişikliklere bağlı olarak artan volatilitenin piyasada oluşan fiyatların bilgi içeriğini azaltabileceğini vurgulamaktadır. Kurumsal yatırımcılar tarafından domine edilen portföylerin kompozisyonu risk algılamalarındaki değişikliklere bağlı olarak piyasa ile ilgili haberlerden hizla etkilenebilirler (Xu ve Malkiel, 2003). Bunun bir sonucu olarak hisse senetlerinin kendilerine özgü oynaklıklarında eşzamanlı 
bir artış başarılı bir çeşitlendirme stratejisinin uygulanmasını engeller. Jiang, Xu ve Yao (2009), gelecekteki gelir şoklarına ilişkin bilgi içeriğinin, kendine özgü risklerin oynaklığının yarattığı risk priminin belirleyicilerinden olduğu sonucuna varmışlardır.

Yoğunlaşan ekonomik rekabet ortamında yatırım firsatlarındaki genişleme beraberinde büyük riskler almaya ve kaybetme riskinin önemli ölçüde artmasına neden olur. Önemli yatırımlar gerektiren benzersiz projeler, hızlı büyüme eğilimindeki şirketlerin giderek artan kendine özgü risk dalgalanmalarına yol açmaktadır (Xu ve Malkiel, 2003). Kayıptan kaçınma (Kahneman ve Tversky, 1979), yatırımcların kararlarında önemli bir rol oynayarak varlığa özgü riskler için itici güç etkisi yapabilir (Malkiel ve $\mathrm{Xu}, 2002 ;$ Bhootra ve Hur, 2015). Guo ve Savickas (2008), varlıkların kendine özgü oynaklığını etkileme konusunda yatırım fırsatlarına karşı riskten korunma taleplerinin önemini göstermiştir. Kendine özgü risklerin volatilitesindeki artış temel nakit akışlarındaki dalgalanmalar ve yoğunlaşan ekonomik rekabet ile ilgili olabilir (Irvine ve Pontiff, 2008).

Konjonktürel dalgalanmaların ve piyasa derinliğinin kendine özgü riskler üzerindeki etkileri çeşitli çalışmalarda ortaya konmuştur (Bekaert, Hodrick ve Zhang, 2012; Karpoff, 1987). Piyasadaki konjoktürel gelişmeler ekonomideki temel parametreleri değiştirerek varlığa özgü riskler üzerindeki etkilerini gösterirler (Bekaert, Hodrick ve Zhang, 2012). Piyasa emirlerinin hisse senedi fiyatları üzerindeki etkisi, işlem hacmi (piyasa derinliği) ile ters orantılıdır (Grossman ve Stiglitz, 1980; Kyle, 1989).

\section{Kendine Özgü Riskin Ölçümü}

Otoregresif Koşullu Değişen Varyans (ARCH) ve Genelleştirilmiş Otoregresif Koşullu Değişen Varyans (GARCH) modellerini kullanan Engle (1982) ve Bollerslev (1986), koşullu değişen varyansı göz önünde bulundurarak varlık fiyatlarındaki dalgalanmaları incelemişlerdir. Üstel GARCH (EGARCH) modeli (Nelson, 1991), negatif ve pozitif şokların gelecekteki varyans üzerindeki farklı etkilerini dikkate almıştır. Fu (2009) EGARCH modelini kullanarak kendine özgü risklerin zamanla değişen karakteristiklerini ortaya koymuştur. Ayrıca bu çalışma, EGARCH 
modeli kullanarak elde edilen kendine özgü risklerin hisse senetleri fiyatlanmasında önemli bir rol oynadığına yönelik ampirik deliller sunmuştur. Bu bilgiler ışığında, varlık fiyatlarındaki açıklamakta zorlanılan değişiklikleri ve oynaklıkları tanımlamak ve kendine özgü riskleri doğru ölçmek için yapılan uygulamalarda $\mathrm{ARCH} / \mathrm{GARCH}$ modellerini kullanmak tercih edilebilir. Bu tercih ampirik araştırmalarda geleneksel finans yaklaşımlarının açıklamakta zorlandığı kısa vadeli ani fiyat değişikliklerini açıklayacak potansiyele sahip olabilir.

Kendine özgü riskleri farklı metodolojiler kullanarak ölçmek araştırmacıların kendine özgü riskler ve beklenen getiriler arasında farklı ilişkiler bulmalarına neden olmuştur. Ang ve diğ. (2006) çalışmalarında Fama-French 3-faktörlü (1993) zaman serisi regresyonundan elde edilen regresyon hata terimlerinin standart sapmasın dikkate alarak kendine özgü riski ölçmüşlerdir. Bu çalışma daha yüksek düzeyde kendine özgü volatilite riskine daha fazla maruz kalmanın Fama-French 3-faktörlü model (1993) tarafından açılanamayan daha düşük ortalama hisse senedi getirilerine yol açtığına yönelik kanıtlar sunmuştur. Jiang ve Lee (2006) hisse senedi piyasalarında kendine özgü risklerin yanlış fiyatlandığına yönelik bulgular elde etmişlerdir. Bu çalışma ayrıca kendine özgü risklerin nasıl ölçüleceği ile ilgili problemlere işaret etmiştir. Ang ve diğ. (2009) global piyasalarda yüksek kendine özgü riskler ile düşük getiriler arasında güçlü bir bağ bulunduğunu belgelemişlerdir. Fu (2009) beklenen getirilerin tahmininde doğru çıkarımlar yapabilmek için kendine özgü risklerin zamanla değişen doğasına vurgu yapmıştır. Bu çalışma, Fama-French 3-faktörlü (1993) zaman serisi regresyonundan elde edilen regresyon hata terimlerinin standart sapması yerine, zamanla değişen kendine özgü risk karakteristiklerini dikkate almak için EGARCH modelini kullanmanın önemine dikkat çekmiştir. Fu'nun (2009) bulguları kendine özgü riskler ile beklenen getiriler arasındaki ilişkinin pozitif olduğunu göstermiştir. Bu yatırımcıların zamanla değişen risklere karşı daha fazla getiri talep etmesi gerektiği argümanı ile örtüşür (Merton, 1987) ve Ang ve diğ.'nin (2006, 2009) bulguları ile çelişmektedir. Bu çelişkinin temel nedeni Ang ve diğ. $(2006,2009)$ çalışmalarında statik ölçüm ile elde edilen kendine özgü riskleri kullanırken, Fu (2009) kendine özgü risklerin zamanla değişen karakteristiğini dikkate almıştır. 


\section{Sonuç}

Bu makalede kendine özgü risklerin potansiyel nedenleri ve fiyatlanabileceği iddiası literatürdeki ilgili çalışmalar ışığında tartışılmıştır. Yukarıda bahsedilen çalışmaların bulgularından anlaşılacağı üzere kendine özgü risklere maruziyetin iyi çeşitlendirilmiş bir portföy yolu ile azaltılabilmesinin davranışsal nedenler, piyasanın etkin bir şekilde işleyememesi, piyasadaki bilgi eksikliği ve asimetrisi ve yatırımcıların dinamik bir şekilde konjonktürel gelişmelere bağlı olarak zamanla değişebilen riskten korunma stratejileri nedeniyle oldukça zor olduğu anlaşılmaktadır.

Yatırımcıların büyük bir kısmı gelecekteki nakit akışlarına ilişkin beklentilere odaklanmaktadır. Bu noktada beklentilerdeki olumsuz havadan etkilenen ekonomik bir iklim nakit akışları ile ilgili kaygıları arttırmaktadır. Yatırımcıların piyasa beklentilerine bağlı olarak farklılaşan stratejileri kendine özgü riskleri önemli ölçüde etkiler (Levy, 1978). Dolayısı ile, özellikle kısa vadede, yatırım firsatlarındaki bozulma kaygısı nedeniyle aniden gerçekleşen riskten kaçınma eğilimi ve bu nedenle risk algılarındaki anlık değişikliklerin yatırımcıların yatırım stratejilerini nasıl etkilediğini iyi anlamak geleneksel finans teorilerinin tahmin ettiği beklenen getirilerden sapmaları izah etmekte önem arz etmektedir. Bu noktada kendine özgü risklerin temelinde olan potansiyel nedenleri doğru tespit edebilmek için güçlü bir teorik çerçeve ortaya konmalı ve bu çerçevede kapsamlı bir ampirik araştırma ile bunların piyasa mekanizmasındaki rolleri incelenmelidir.

Bir diğer önemli husus konjonktürel dalgalanmalara bağlı olarak getiriler üzerindeki etkisi değişen kendine özgü risklerin nasıl elde edilebileceği meselesidir. Kendine özgü risklerin statik ölçümlerinin ve bu risklerin zamanla değişen karakteristiklerini dikkate alan dinamik modeller kullanılarak yapılan ölçümlerinin beklenen getirileri açıklamaktaki yetenekleri doğal olarak farklılaşır. Bu nedenle, kendine özgü riskler üzerine yapilacak incelemelerin ve bu incelemelere dayanan yorumların bu risklerin nasıl elde edildiği dikkate alınarak yapılması bilimsel tartışmaların sağlıklı olabilmesi için önemlidir. 


\title{
EXTENDED ABSTRACT
}

\section{A Literature Review on Idiosyncratic Risks}

\author{
Barış Kocaarslan
}

Yalova University

In the literature, it is a prominent argument that market players can reduce the idiosyncratic risk of assets that they have through diversifying their portfolios (Markowitz, 1952). However, this argument remains a controversial issue among researchers. It is argued that the main reason for this discussion is due to the limitations and assumptions of the wellknown financial asset pricing models. Therefore, we first mention the assumptions and perspectives of traditional finance approaches in this study. Then, we discuss the findings and implications of the related studies on the causes and characteristics of idiosyncratic risks. Finally, we mention some of the recommendations in the literature on which models to use for the measurement of idiosyncratic risk.

In the asset pricing literature, several well-known finance theories have studied the effects of common risk factors on the fundamental value of an asset. The observed market prices are determined by supplydemand equilibrium in the market mechanism. On one hand, asset prices show deviations from their fundamental value due to various reasons, especially in the short term. On the other hand, the observed price tends to converge to the fundamental value in the long run (Smith, 1776). The efficient market hypothesis (Fama, 1970) is based on the assertion that the observed price and fundamental value are very close to each other. In sum, the main discussion on asset pricing models is related to how close the observed price is to the fundamental value.

Having an asset allows us to claim rights on future cash flows that investment on the asset will provide. From this point of view, the fundamental value of an asset depends on expected cash flows in the future. 
The present value model is based on the premise that expected cash flows (dividend payments) are discounted to the present value at an appropriate discount rate (Campbell, Lo and MacKinlay, 1997). However, in order to obtain the present value of an asset, it is difficult to estimate the dividend yield and determine the appropriate discount rate. Efficient market hypothesis (EMH hereafter) (Fama, 1970) argues that based on available information, we can explain the fundamental value of the assets and ultimately their market prices. EMH assumes that there is a consensus among market participants on market expectations since forming future expectations depends on the information available to the participants. Nevertheless, subjective ideas and risk perceptions based on asset-specific characteristics also play an important role in forming expectations on future cash flows. The empirical studies provide several findings that the present-value model and other static models, such as Capital Asset Pricing Model (Sharpe, 1964; Lintner, 1965), are sometimes insufficient to explain the variations in asset prices because they do not take into account time-varying risk properties of assets. This implies that rather than using static model, dynamic models, which consider timevarying risk factors, need to be taken into account.

In sum, the estimates from finance theories based on various assumptions and predetermined risk factors generally do not exactly match the observed market prices. In addition to the common risk factors that these theories take into consideration, this points out the possibility that the idiosyncratic risks of firms and industries could be priced. It is observed that static models have more difficulty in explaining the fluctuations in asset prices, especially in the short term, compared to dynamic models. One of the main reasons for this difficulty is that the volatility of an asset suddenly and significantly changes over time, depending on the differentiated expectations of investors regarding future market conditions (Levy, 1978).

The existing literature provides strong evidence of the effects of idiosyncratic risk on expected returns (Levy, 1978; Barberis and Huang, 2001; Goyal and Santa-Clara, 2003). Effective investment strategies require careful risk management to adjust volatility exposure to idiosyncratic (non-systematic) risks. The behavior of the assets differs from one another due to the fluctuations in economic conditions depending on their 
underlying characteristics. Therefore, the idiosyncratic risks of individual stocks inherently change over time. For this reason, fund managers who develop effective investment strategies should continuously update the composition of their portfolios in order to be protected from the idiosyncratic risk exposure, especially in periods of increasing volatility. Campbell et al. (2001) document that diversification strategies require a large number of stocks to be included in portfolios with different characteristics.

In this paper, the potential reasons behind idiosyncratic risks are discussed in the light of the previous findings in the related literature. Previous literature indicates that the reduction of exposure to idiosyncratic risks through a well-diversified portfolio is quite difficult due to behavioral reasons, the insufficient functioning of the market, lack of information and information asymmetry in the market, and time-varying investment strategies of investors due to cyclical developments in the economy.

Most investors focus on expectations for future cash flows. At this point, the deteriorating economic conditions increase concerns about the cash flows. Differentiated investment strategies of investors depending on market expectations significantly affect idiosyncratic risks (Levy, 1978). Thus, particularly in the short term, it is important to explain the sudden changes in the risk aversion of investors due to worsening business conditions affecting investors' investment strategies. A strong theoretical framework should be established in order to determine the potential causes behind the idiosyncratic risks and a comprehensive empirical research on their role in the market mechanism should be examined.

Another important issue is the question of how idiosyncratic risks, whose impact on expected returns changes due to cyclical fluctuations in economic activity, can be obtained. The previous literature documents that the ability of idiosyncratic risk factor in explaining the expected returns differs depending on the static and dynamic measurements of idiosyncratic risk. To this respect, considering how idiosyncratic risk is obtained is important to make a better scientific discussion and, hence, to better interpret main findings regarding the impact of idiosyncratic risks on expected returns. 


\section{Kaynakça/References}

Ang, A., Hodrick, R. J., Xing, Y., ve Zhang, X. (2006). The cross-section of volatility and expected returns. The Journal of Finance, 61(1), 259-299.

Ang, A., Hodrick, R. J., Xing, Y., ve Zhang, X. (2009). High idiosyncratic volatility and low returns: International and further US evidence. Journal of Financial Economics, 91(1), 1-23.

Bali, T. G., Cakici, N., Yan, X., ve Zhang, Z. (2005). Does idiosyncratic risk really matter?. The Journal of Finance, 60(2), 905-929.

Barberis, N., ve Huang, M. (2001). Mental accounting, loss aversion, and individual stock returns. The Journal of Finance, 56(4), 1247-1292.

Bekaert, G., Hodrick, R. J., ve Zhang, X. (2012). Aggregate idiosyncratic volatility. Journal of Financial and Quantitative Analysis, 47(6), 1155-1185.

Bhootra, A., ve Hur, J. (2015). High idiosyncratic volatility and low returns: A prospect theory explanation. Financial Management, 44(2), 295-322.

Black, F., (1976). Studies of stock price volatility changes. Proceedings of the 1976 Meetings of the Business and Economic Statistics Section, 177181, American Statistical Association.

Bollerslev, T. (1986). Generalized autoregressive conditional heteroskedasticity. Journal of Econometrics, 31(3), 307-327.

Campbell, J. Y., Lettau, M., Malkiel, B. G., ve Xu, Y. (2001). Have individual stocks become more volatile? An empirical exploration of idiosyncratic risk. The Journal of Finance, 56(1), 1-43.

Campbell, J. Y., Lo, A. W., ve MacKinlay, A. C. (1997). The econometrics of financial markets (Vol. 2, pp. 149-180). Princeton, NJ: princeton University press.

Christie, A. A. (1982). The stochastic behavior of common stock variances: Value, leverage and interest rate effects. Journal of Financial Economics, 10(4), 407-432.

Engle, R. F. (1982). Autoregressive conditional heteroscedasticity with estimates of the variance of United Kingdom inflation. Econometrica: Journal of the Econometric Society, 987-1007.

Fama, E. F., (1970). Efficient Capital Markets: A Review of Theory and Empirical Work. The Journal of Finance, vol. 25, 383-417.

Fama, E. F., ve French, K. R. (1993). Common risk factors in the returns on stocks and bonds. Journal of Financial Economics, 33(1), 3-56. 
Fu, F. (2009). Idiosyncratic risk and the cross-section of expected stock returns. Journal of Financial Economics, 91(1), 24-37.

Goyal, A., ve Santa-Clara, P. (2003). Idiosyncratic risk matters!. The Journal of Finance, 58(3), 975-1007.

Grossman, S. J., ve Stiglitz, J. E. (1980). On the impossibility of informationally efficient markets. The American economic review, 70(3), 393-408.

Grossman, S. J. (1988). An Analysis of the Implications for Stock and Futures Price Volatility of Program Trading and Dynamic Hedging Strategies. Journal of Business, 275-298.

Guo, H., ve Savickas, R. (2008). Average idiosyncratic volatility in G7 countries. The Review of Financial Studies, 21(3), 1259-1296.

Irvine, P. J., ve Pontiff, J. (2008). Idiosyncratic return volatility, cash flows, and product market competition. The Review of Financial Studies, 22(3), 1149-1177.

Jiang, G. J., Xu, D., ve Yao, T. (2009). The information content of idiosyncratic volatility. Journal of Financial and Quantitative Analysis, 44(1), 1-28.

Jiang, X., ve Lee, B. S. (2006). The dynamic relation between returns and idiosyncratic volatility. Financial Management, 35(2), 43-65.

Kahneman, D., ve Tversky, A. (1979). Prospect Theory: An Analysis of Decision under Risk. Econometrica, 47(2), 263-292.

Karpoff, J. M. (1987). The relation between price changes and trading volume: A survey. Journal of Financial and Quantitative Analysis, 22(1), 109-126.

Kyle, A. S. (1989). Informed speculation with imperfect competition. The Review of Economic Studies, 56(3), 317-355.

Levy, H. (1978). Equilibrium in an Imperfect Market: A Constraint on the Number of Securities in the Portfolio. The American Economic Review, 68(4), 643-658.

Lintner, J. (1965). Security prices, risk, and maximal gains from diversification. The Journal of Finance, 20(4), 587-615.

Malkiel, B. G., ve Xu, Y. (2002). Idiosyncratic risk and security returns. University of Texas at Dallas (November 2002).

Markowitz, H. (1952). Portfolio selection. The Journal of Finance, 7(1), 77-91.

Merton, R. C. (1987). A simple model of capital market equilibrium with incomplete information. The Journal of Finance, 42(3), 483-510. 
Nelson, D. B. (1991). Conditional heteroskedasticity in asset returns: A new approach. Econometrica: Journal of the Econometric Society, 347-370.

Sharpe, W. F. (1964). Capital asset prices: A theory of market equilibrium under conditions of risk. The Journal of Finance, 19(3), 425-442.

Smith, A. (1776). An inquiry into the nature and causes of the wealth of nations: Volume One. London: printed for W. Strahan; and T. Cadell, 1776.

Stein, J. C. (1987). Informational externalities and welfare-reducing speculation. Journal of Political Economy, 95(6), 1123-1145.

Xu, Y., ve Malkiel, B. G. (2003). Investigating the behavior of idiosyncratic volatility. The Journal of Business, 76(4), 613-645.

\section{Kaynakça Bilgisi / Citation Information}

Kocaarslan, B. (2018). Kendine özgü riskler üzerine bir literatür derlemesi. OPUS-Uluslararası Toplum Araştırmaları Dergisi, 9(16), 18371850. DOI: $10.26466 /$ opus. 480916 